\title{
Evidence for significant protein-like dissolved organic matter accumulation in Sea of Okhotsk sea ice
}

\author{
Mats A. GRANSKOG, ${ }^{1}$ Daiki NOMURA, ${ }^{2}$ Susann MÜLLER, ${ }^{3}$ Andreas KRELL, ${ }^{4}$ \\ Takenobu TOYOTA, ${ }^{2}$ Hiroshi HATTORI ${ }^{5}$ \\ ${ }^{1}$ Norwegian Polar Institute, Fram Centre, Tromsø, Norway \\ E-mail: mats@npolar.no \\ ${ }^{2}$ Institute of Low Temperature Science, Hokkaido University, Sapporo, Hokkaido, Japan \\ ${ }^{3}$ Department of Biological and Environmental Sciences, University of Helsinki, Helsinki, Finland \\ ${ }^{4}$ Alfred-Wegener-Institut Helmholtz-Zentrum für Polar- und Meeresforschung, Bremerhaven, Germany \\ ${ }^{5}$ Tokai University, Minamisawa, Minamiku Sapporo, Hokkaido, Japan
}

\begin{abstract}
Absorption and fluorescence of chromophoric dissolved organic matter (CDOM) in sea ice and surface waters in the southern Sea of Okhotsk was examined. Sea-water CDOM had featureless absorption increasing exponentially with shorter wavelengths. Sea ice showed distinct absorption peaks in the ultraviolet, especially in younger ice. Older first-year sea ice had relatively flat absorption spectra in the ultraviolet range. Parallel factor analysis (PARAFAC) identified five fluorescent CDOM components, two humic-like and three protein-like. Sea water was largely governed by humic-like fluorescence. In sea ice, protein-like fluorescence was found in considerable excess relative to sea water. The accumulation of protein-like CDOM fluorescence in sea ice is likely a result of biological activity within the ice. Nevertheless, sea ice does not contribute excess CDOM during melt, but the material released will be of different composition than that present in the underlying waters. Thus, at least transiently, the CDOM introduced during sea-ice melt might provide a more labile source of fresher protein-like DOM to surface waters in the southern Sea of Okhotsk.
\end{abstract}

KEYWORDS: sea ice, sea-ice ecology

\section{INTRODUCTION}

The Sea of Okhotsk belongs to the seasonal sea-ice zone and is at the lowest latitude at which sea ice is found (besides the Bohai Sea), with maximum ice extent of $50-90 \%$ in late winter (Granskog and others, 2010). Most of the sea ice is produced in the northern continental shelf region (Martin and others, 1998). Sea-ice extent is largely controlled by wind, and sea ice is transported from north to south (Granskog and others, 2010, and references therein). The northern Sea of Okhotsk also receives significant terrestrial inputs of dissolved organic matter (DOM) from the Amur River, which during ice formation are injected to deeper waters, together with brine, and transported in the subsurface into the southern Sea of Okhotsk and further to the Pacific (e.g. Nakatsuka and others, 2004). Further south, water masses are composed of a mixture of waters entering the region, where the Soya current brings warmer waters from the Japan Sea, Pacific waters enter through the Kuril Straits, and the Sakhalin current transports waters from the northern shelf to the south.

In contrast, the water masses in the eastern part of Saroma-ko lagoon, located adjacent to the Sea of Okhotsk on the northern shore of Hokkaido, Japan, consist mainly of adjacent Okhotsk Sea water, the freshwater input from the Saromabetsu River and seasonally of ice melt (Shirasawa and Leppäranta, 2003; Nomura and others, 2009). Almost the entire surface of Saroma-ko lagoon is generally covered with sea ice from early January through early April, with large year-to year variability.

Chromophoric DOM (CDOM) is ubiquitous in marine environments and can make up a substantial proportion of the DOM pool in aquatic systems (Thurman, 1985), representing up to $60 \%$ of the bulk dissolved organic carbon (DOC) pool (Ertel and others, 1986). DOM is a major source of energy for heterotrophs, and thus CDOM plays an important role in the biogeochemistry of natural waters (Hansell and Carlson, 2002). CDOM exerts a significant influence on the optical properties of ocean water and sea ice. For example, it affects the penetration of ultraviolet radiation (known to inhibit phytoplankton productivity), the light available for primary production, and the distribution of radiant heating in sea ice and surface ocean and thereby surface stratification (e.g. Mopper and Kieber, 2002; Ehn and others, 2004; Granskog and others, 2007; Hill, 2008; Uusikivi and others, 2010). Further, exposure to light can have a significant effect on the cycling of DOM, as the absorption of ultraviolet and visible light initiates the formation of a number of reactive products, including biologically labile ammonium and phosphate, and the remineralization of carbon (e.g. Moran and Zepp, 1997; Obernosterer and Benner, 2004; Vähätalo and Zepp, 2005). The optical properties of CDOM in Baltic Sea ice differ from those of the underlying sea water (Ehn and others, 2004) as a result of in situ CDOM production (Stedmon and others, 2007), most likely by sympagic (ice-associated) organisms, resulting in protein-like compounds that dominate over humic-like fluorescence, contrary to parent sea water. In Antarctic sea ice, where marine DOM dominates, the CDOM composition is also markedly different from that in underlying sea water, suggesting autochthonous CDOM production and accumulation in sea-ice brines (Stedmon and others, 2011), potentially making sea ice an important source of labile CDOM during sea-ice melt (Norman and others, 2011). 


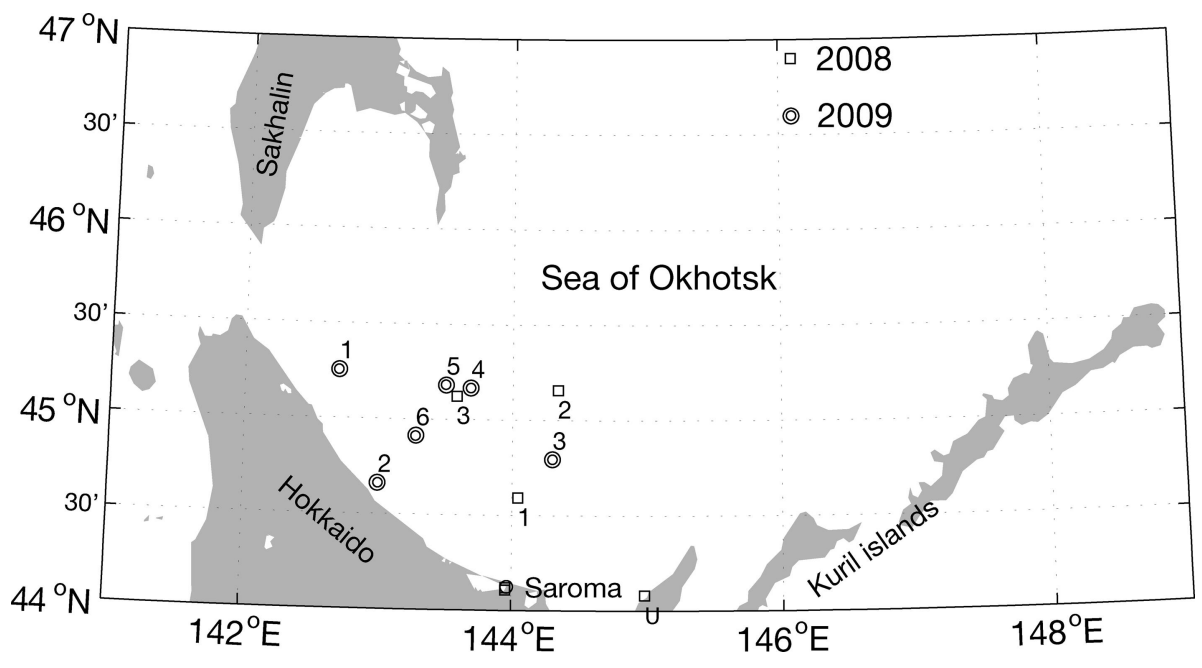

Fig. 1. Location of sampling sites in 2008 (squares; station number below symbol) and 2009 (circles; station number above symbol) in the southern Sea of Okhotsk. Saroma-ko lagoon (Saroma) and Utoro (U) sampling sites are also indicated.

Sea-ice studies in the Sea of Okhotsk have mainly focused on understanding the physical characteristics of sea ice (Ukita and others, 2000; Toyota and others, 2004, 2007). The amount of particulate impurities in sea ice has been reported by Granskog (2000), but studies on the biogeochemistry of sea ice are limited (McMinn and others, 2008; Nomura and others, 2010, 2011). Since sea ice is mainly produced in the northern region of the Sea of Okhotsk and transported to the south where it melts (e.g. Kimura and Wakatsuchi, 2004), besides fluxes of heat and fresh water, sea ice is also potentially important for the supply of any material accumulated in, or transported with, the ice (Nomura and others, 2010). In this case, the southern Sea of Okhotsk is the main region receiving inputs from melting sea ice. In contrast to the Sea of Okhotsk, several studies on Saroma-ko lagoon report on the biogeochemistry and sympagic assemblages in sea ice (e.g. Robineau and others, 1997; McMinn and Hattori, 2006; Nomura and others, 2009, 2011).

We hypothesize that there are contrasting regimes in DOM composition, both spatially between Okhotsk and Saroma-ko lagoon, but also between sea water and sea ice, which might result in a flux of compositionally different DOM by sea-ice melt (cf. Norman and others, 2011). With this in mind, we examine the composition of CDOM in sea ice and under-ice waters in the southern Sea of Okhotsk and the adjacent Saroma-ko lagoon in late winter and spring. We present the first data on CDOM absorbance and fluorescence of sea ice in the region, as well as in underlying surface waters. The main objective of this study is to describe the optical characteristics and possible origin of CDOM, and discuss the potential role of sea ice as a source of $\mathrm{CDOM}$ in the region.

\section{MATERIALS AND METHODS}

\section{Study area}

Samples were collected from pack ice in the southern Sea of Okhotsk during two cruises on board the Japanese Coast Guard vessel Soya on 11-13 February 2008 and 9-12 February 2009, from landfast ice during land-based sampling in Saroma-ko lagoon (hereafter Saroma) on 3-4 March 2008 and 20 February 2009 (Fig. 1, Saroma), and from nearshore drift ice during land-based sampling off the Utoro Peninsula in the southeastern Sea of Okhotsk on 7 March 2008 (Fig. 1, site U). At each location sea ice and under-ice water (1-3 $\mathrm{m}$ from the ice underside) were collected. In total 14 sites were sampled (Table 1), with 14 sea-water samples and 51 ice sections (see below).

\section{Field sampling and sample processing}

Sea-ice samples were collected using an ice corer (Mark II, Kovacs Enterprises, Inc., USA). One core was used to measure ice temperature (Testo 110 NTC, Brandt Instruments, Inc., USA); a second core was used for the analyses. In 2009, pancake and nilas ice (Table 1) were sampled from a basket lowered from the ship to the sea surface. One half of the core or part of the collected ice was used for immediate processing and subsampling. The other half of the core was placed in plastic tubing or bags and stored in an on-board freezer at $-15^{\circ} \mathrm{C}$.

For pigment analysis, ice samples were cut into sections, usually every 5 or $10 \mathrm{~cm}$, and melted directly on board the ship with the addition of artificial sea water (salinity 40). Samples were melted at room temperature in the dark in acid-washed lidded Teflon cups.

The second half of the ice-core samples from the Soya expeditions were placed in polyethylene tubing immediately after collection and kept horizontal in a freezer (at $-15^{\circ} \mathrm{C}$ ) during the cruise. These half-core samples from Soya for CDOM, salinity and $\delta^{18} \mathrm{O}$ analyses were processed in the freezer room at Hokkaido University shortly after each cruise. The core half was cut into a $4 \mathrm{~cm} \times 3 \mathrm{~cm}$ rectangular cross section and then cut into sections. To avoid contamination during sampling and handling processes, $3 \mathrm{~mm}$ of the outside of the ice sections were removed with a clean stainless-steel plane. The remaining ice was placed in an acid-washed Teflon cup for melting at room temperature in the dark.

Sea-ice samples from land-based sampling in Saroma and Utoro were processed directly on site (pigment analysis). Immediately after retrieval the samples were cut into $5-10 \mathrm{~cm}$ sections and placed in pre-cleaned lidded polyethylene cups for melting. Samples for pigment analysis were melted as for the samples from Soya. Frozen cores were taken to Hokkaido University in Sapporo and 
Table 1. Sampling sites and conditions

\begin{tabular}{|c|c|c|c|c|c|c|}
\hline Station & Date & Position & $\mathrm{cm}$ & $\begin{array}{l}\text { Sea-water } \\
\text { salinity at } \\
3 \mathrm{~m} \text { depth }\end{array}$ & $\begin{array}{l}\text { Bulk ice } \\
\text { salinity }\end{array}$ & Remarks \\
\hline Soya 1 & 11 Feb 2008 & $44.59203^{\circ} \mathrm{N}, 144.0437^{\circ} \mathrm{E}$ & 35 & 32.26 & 5.43 & First-year ice. Pack ice \\
\hline Soya 2 & 12 Feb 2008 & $45.15785^{\circ} \mathrm{N}, 144.3377^{\circ} \mathrm{E}$ & 60 & 32.46 & 5.20 & First-year ice. Pack ice \\
\hline Soya 3 & 13 Feb 2008 & $45.12296^{\circ} \mathrm{N}, 143.5815^{\circ} \mathrm{E}$ & 30 & 32.32 & 4.45 & First-year ice. Pack ice \\
\hline Utoro & 7 Mar 2008 & $44.0804^{\circ} \mathrm{N}, 144.9809^{\circ} \mathrm{E}$ & 75 & 32.11 & 3.50 & $\begin{array}{c}\text { First-year ice. Pack ice attached to coast. } \\
\text { Heavily deformed }\end{array}$ \\
\hline Saroma R & 4 Mar 2008 & $44.1074^{\circ} \mathrm{N}, 143.9542^{\circ} \mathrm{E}$ & 40 & $\mathrm{n} / \mathrm{a}$ & 2.81 & $\begin{array}{l}\text { Fast ice. Heavily impacted by runoff and } \\
\text { snow ice }\end{array}$ \\
\hline Saroma M & 3 Mar 2008 & $44.1197^{\circ} \mathrm{N}, 143.9557^{\circ} \mathrm{E}$ & 44 & 32.50 & 3.43 & $\begin{array}{l}\text { Heavily impacted by runoff and snow } \\
\text { ice. Brown ice algae layer at ice bottom }\end{array}$ \\
\hline Soya 1 & 9 Feb 2009 & $45.2539^{\circ} \mathrm{N}, 142.7000^{\circ} \mathrm{E}$ & 11 & 32.40 & 9.18 & Pancake $(<1 \mathrm{~m}$ in diameter $)$ \\
\hline Soya 3 & 10 Feb 2009 & $44.7942^{\circ} \mathrm{N}, 144.2981^{\circ} \mathrm{E}$ & 3 & 32.14 & 5.65 & Nilas \\
\hline Soya 4 & 11 Feb 2009 & $45.1664^{\circ} \mathrm{N}, 143.6850^{\circ} \mathrm{E}$ & 64 & 32.48 & 6.01 & First-year ice. Floe $\varnothing 20$ m \\
\hline Soya 5 & 12 Feb 2009 & $45.1808^{\circ} \mathrm{N}, 143.5000^{\circ} \mathrm{E}$ & 7 & 32.47 & 4.27 & Nilas \\
\hline Soya 6 & 12 Feb 2009 & $44.9119^{\circ} \mathrm{N}, 143.2789^{\circ} \mathrm{E}$ & 4.5 & 32.00 & 6.85 & Nilas \\
\hline Saroma 1 & 20 Feb 2009 & $\mathrm{n} / \mathrm{a}$ & 20 & $31.40^{*}$ & 4.73 & Warm and porous ice. Mild winter \\
\hline Saroma 2 & 20 Feb 2009 & $44.1241^{\circ} \mathrm{N}, 143.9676^{\circ} \mathrm{E}$ & 25 & $31.60^{*}$ & 5.66 & Warm and porous ice. Mild winter \\
\hline
\end{tabular}

*1 m depth.

processed for salinity, $\delta^{18} \mathrm{O}$ and CDOM analyses as described for the samples from Soya.

Under-ice water samples were collected on all occasions through the ice-core holes using a $500 \mathrm{~mL}$ Teflon water sampler (GL Science Inc., Japan), usually at $3 \mathrm{~m}$ depth (Table 1), $15 \mathrm{~min}$ after drilling of ice cores to avoid disturbance caused by drilling.

Melted sea ice and under-ice water were subsampled for salinity and oxygen isotopic ratio $\left(\delta^{18} \mathrm{O}\right)$ measurements into $10 \mathrm{~mL}$ glass vials, and $40 \mathrm{~mL}$ pre-combusted amber glass vials for CDOM. Salinity and $\delta^{18} \mathrm{O}$ samples were kept at room temperature $\left(+15^{\circ} \mathrm{C}\right)$. CDOM samples were filtered through PALL Acrodisk ${ }^{\circledR}$ membrane filters (Supor ${ }^{\circledR}$ membrane, pore size $0.2 \mathrm{~m}$, with $0.8 \mathrm{~m}$ Supor ${ }^{\circledR}$ pre-filter) using acid-washed all-plastic syringes. Ultrapure water treated as samples showed no trace of leaching of CDOM into the samples during melting, filtering and storage. CDOM samples were stored in the dark at $+4^{\circ} \mathrm{C}$. Samples of known volume were filtered onto Whatman GF/F glassfiber filters (nominal pore size $0.7 \mathrm{~m}$ ) using low vacuum for pigment analysis. Filters were placed in liquid nitrogen until measurements were conducted.

\section{Analytical methods}

Salinity was measured using a salt analyzer (SAT-210; Toa Electronics Ltd, Japan). A standard deviation for salinity calculated from 15 subsamples taken from a reference water sample $(S=10.00)$ was 0.03 . $\delta^{18} \mathrm{O}$ was determined with a mass spectrometer (DELTA plus; Finnigan MAT, USA). Results are reported as $\delta^{18} \mathrm{O}(\%)$, defined as the deviation of $\mathrm{H}_{2}{ }^{18} \mathrm{O} / \mathrm{H}_{2}{ }^{16} \mathrm{O}$ ratio of the measured sample to that of Vienna Standard Mean Ocean Water (VSMOW). The precision of $\delta^{18} \mathrm{O}$ analysis from duplicate determinations is $\pm 0.02 \%$ (Toyota and others, 2007). Chlorophyll a (Chl a) was determined with high-performance liquid chromatography (HPLC; Shimadzu SPD-M10AVvp with Class-VP Multi Workstation) following the methods of Furuya and others (1998).
CDOM spectral absorbance $(A(\lambda))$ was measured using a Shimadzu UV-PC2501 spectrophotometer with a $10 \mathrm{~cm}$ quartz cell, from 190 to $800 \mathrm{~nm}$, with $2 \mathrm{~nm}$ slits and at $1 \mathrm{~nm}$ intervals, after samples had been allowed to warm to room temperature, with ultrapure water (Milli-Q) as reference. A baseline correction was carried out, with average absorbance at $690-710 \mathrm{~nm}$ subtracted from the spectra. Absorbance was converted to absorption coefficients $\left(a_{\mathrm{CDOM}}(\lambda)\left(\mathrm{m}^{-1}\right)=\right.$ $[2.303 A(\lambda)] / 0.1 \mathrm{~m})$. CDOM samples were measured within 2-3 months after collection. The spectral slope coefficient $S$ at $250-400 \mathrm{~nm}$ range was calculated using a linear fit to logtransformed absorption data.

The CDOM fluorescence was measured using a Varian Cary spectrofluorometer with excitation at $240-450 \mathrm{~nm}$ (every $5 \mathrm{~nm}$ ), and the resulting emission was measured from 300 to $600 \mathrm{~nm}$ (every $2 \mathrm{~nm}$ ). The resulting excitationemission matrices (EEMs) were corrected for instrumentspecific spectral corrections, inner filter effects (based on the absorption of the sample) and Raman and Rayleigh scattering, and finally converted to Raman units (RU) based on the Raman signal from ultrapure water (ultrapure water was run as a sample for each batch of samples measured to account for possible instrument drift). Corrected fluorescence data (i.e. EEMs) were analyzed using the DOMFluor Toolbox v1.7 (Stedmon and Bro, 2008).

\section{PARAFAC modeling}

A total of 65 EEMs were collected and modeled in this study, which included 14 sea-water samples and 51 samples from sea-ice cores. However, the dataset was very diverse; it was not collected along a mixing gradient or time series, but contained extreme samples. Therefore it is not ideal for parallel factor analysis (PARAFAC) modeling (see Stedmon and Bro, 2008). Thus weighing was carried out in accordance with Kowalczuk and others (2009), who also had a diverse EEM dataset. Samples with extremely high fluorescence were diluted, such that all samples were within a maximum intensity range of $0-0.5 \mathrm{RU}$. This 
Table 2. Primary and secondary excitation-emission (Ex/Em) peaks for PARAFAC model components on Okhotsk sea ice and surface waters. Median EFs for components in sea ice relative to underlying sea water

\begin{tabular}{lccc}
\hline Component & $\begin{array}{c}\text { Primary peak } \\
\text { Ex/Em }\end{array}$ & $\begin{array}{c}\text { Secondary peak } \\
\text { Ex/Em }\end{array}$ & $\begin{array}{c}\text { EF } \\
\text { median }\end{array}$ \\
\hline C1 & $250 / 385$ & $295 / 385$ & 3.9 \\
C2 & $260 / 442$ & $340 / 442$ & 2.8 \\
C3 & $280 / 342$ & $250 / 342$ & 14.0 \\
C4 & $275 / 305$ & & 10.2 \\
C5 & $250 / 305$ & & 8.9 \\
\hline
\end{tabular}

weighed dataset was split-half validated for a five-component PARAFAC model, and a residual analysis also confirmed that a five-component model was appropriate (Stedmon and Bro, 2008). Table 2 lists the excitation and emission peaks of the components derived for the validated PARAFAC model. The fluorescence intensities in the subsequent data analysis refer to the maximum fluorescence signals of each component.

\section{RESULTS AND DISCUSSION}

\section{Sea-water and sea-ice characteristics}

In 2008 the ice sampled was first-year ice ( $>0.3 \mathrm{~m}$ thick), while in 2009 the majority of the ice sampled in the Sea of Okhotsk was young ice, pancake ice or dark nilas $(<0.3 \mathrm{~m}$ thick). This is reflected in the higher salinity of the younger ice (Table 1). From previous studies it is known that snow can contribute significantly to sea-ice mass both in the southern Sea of Okhotsk (Ukita and others, 2000; Toyota and others, 2007; Nomura and others, 2010) and in Saroma (Shirasawa and others, 2005; Nomura and others, 2011), although considerably more so in the latter. Our observations concurred with earlier observations: in $2008 \sim 10 \%$ of the total length of the Okhotsk ice samples was snow-ice, while in Saroma snow-ice contributed $30-40 \%$ of the total ice thickness based on $\delta^{18} \mathrm{O}$ composition. Dynamic thickening and rafting of young floes contributed significantly in the Sea of Okhotsk in 2008. In 2009, as mainly new or young ice was sampled, the snow contribution to ice mass was negligible in the Okhotsk samples. In Saroma, snow-ice again contributed significantly, although less than in 2008.

Yamamoto and others $(2001,2002)$ proposed that deviations in sea-water composition (salinity and $\delta^{18} \mathrm{O}$ ) from the western sub-arctic Pacific water (WSAP) line $\left(\delta^{18} \mathrm{O}=0.3915 \times\right.$ salinity $-13.561, R^{2}=0.99, n=59$; Yamamoto and others, 2001) can be used to explain the mechanism behind the sea-water composition. Our data are mainly displaced in a manner consistent with the addition of meteoric water (lighter $\delta^{18} \mathrm{O}$ ) and brine from seaice formation (higher salinity), relative to the WSAP line (not shown) in both Saroma and Okhotsk samples. Samples collected $3 \mathrm{~m}$ below the ice bottom (2008) might not capture the shallow fresher under-ice layer in Saroma (see Nomura and others, 2009), which is reflected in the lower salinity (Table 1) and light isotope values for under-ice water collected $1 \mathrm{~m}$ below the ice bottom in Saroma in 2009 (not shown).

\section{Algal biomass}

The algal biomass in sea ice in Saroma ranged from 2.0 to $9.0 \mathrm{mg} \mathrm{Chl} \mathrm{a} \mathrm{m}^{-2}$ in 2008 and 0.3 to $10.6 \mathrm{mg} \mathrm{Chl} \mathrm{am}^{-2}$ in 2009. This contrasts with previous observations which include 272.8 $\pm 20.2 \mathrm{mg} \mathrm{Chl} \mathrm{a} \mathrm{m}^{-2}$ (McMinn and Hattori, 2006), 2-119 $\mathrm{mg} \mathrm{Chl} \mathrm{a} \mathrm{m}^{-2}$ (Robineau and others, 1997) and $38.25 \mathrm{mg} \mathrm{Chl} \mathrm{a} \mathrm{m}^{-2}$ (Kudoh and others, 1997). Although biomass in Saroma was thus lower than in earlier studies, biomass in Okhotsk ice was even lower than in Saroma, where it ranged from 0.2 to $1.6 \mathrm{mg} \mathrm{Chl} \mathrm{a} \mathrm{m}^{-2}$ in 2008 and from 0.0 to $3.5 \mathrm{mg} \mathrm{Chl} \mathrm{a} \mathrm{m}^{-2}$ in 2009 . The ice algal biomass distribution was typically accumulated in the bottom $5-10 \mathrm{~cm}$. In only one core (2008) from Saroma was algal biomass distributed evenly throughout the length of the core (Saroma R station). Chl a levels were up to an order of magnitude lower in under-ice water than in ice, both in Okhotsk and Saroma. The standing stock in the ice cores corresponded to the total algal biomass in $5-15 \mathrm{~m}$ of the under-ice water column at the time of sampling.

\section{CDOM absorption}

Measurements of CDOM absorption in sea water showed the typical featureless exponential decay (e.g. Bricaud and others, 1981) with increasing wavelength, as shown in Figure $2 \mathrm{a}$ and $\mathrm{b}$. Values of absorption at 350 or $375 \mathrm{~nm}\left(\mathrm{a}_{350}\right.$ and $\mathrm{a}_{375}$ ) were higher in Saroma than in Okhotsk waters (Table 3). The spectral slope coefficient $S$ had values between 0.0197 and 0.0280 in Okhotsk and 0.0183 and 0.0202 in Saroma (Table 3). The lower $S$ values in Saroma imply a greater influence from rivers (e.g. Blough and Del Vecchio, 2002), and the lower values in 2009 vs 2008 also exemplify the less saline water sampled in 2009 belonging to a well-developed under-ice plume (Nomura and others, 2009). The majority of the sea-ice samples had local absorption peaks (Fig. 2c and d), which made it impossible to compute $S$ values as the fit was very poor. A distinct peak at $\sim 325 \mathrm{~nm}$ was present in the majority of sea-ice samples, while a secondary peak was visible in some sea-ice samples at $\sim 275 \mathrm{~nm}$. Peaks in CDOM absorbance spectra similar to those observed here were reported by Belzile and others (2000) in ice-core samples from Baffin Bay, Canadian Arctic, and similar peaks have recently been found to be a ubiquitous feature of CDOM in Antarctic sea ice (Norman and others, 2011). Patasayeva and others (2004) observed absorption peaks between 270 and $300 \mathrm{~nm}$ in sea-ice brine samples generated in an ice tank experiment. Similar absorbance spectra have also been found in the CDOM produced by cyanobacteria in culture (Steinberg and others, 2004). The exact source of these peaks is unknown; however, they seem to represent an ice-specific CDOM fraction, i.e. related to autochthonous production, and are suggested to be related to the production of ultravioletabsorbing compounds for photoprotection (e.g. Belzile and others, 2000). It is known that mycosporine-like amino acids (MAAs) absorb strongly at $\sim 330 \mathrm{~nm}$, while at $275-280 \mathrm{~nm}$ aromatic amino acids (precursors to MAAs) and some nucleic acids absorb strongly (e.g. Woźniak and Dera, 2007). All these compounds are produced by marine organisms. MAAs were almost completely absent at the bottom of thick Antarctic sea ice (Ryan and others, 2002), likely due to low exposure to ultraviolet light. In thin (snowfree) seasonal sea ice in the Baltic Sea, more representative of the conditions in the Sea of Okhotsk or Saroma, concentrations of MAAs were exceptionally high (with 

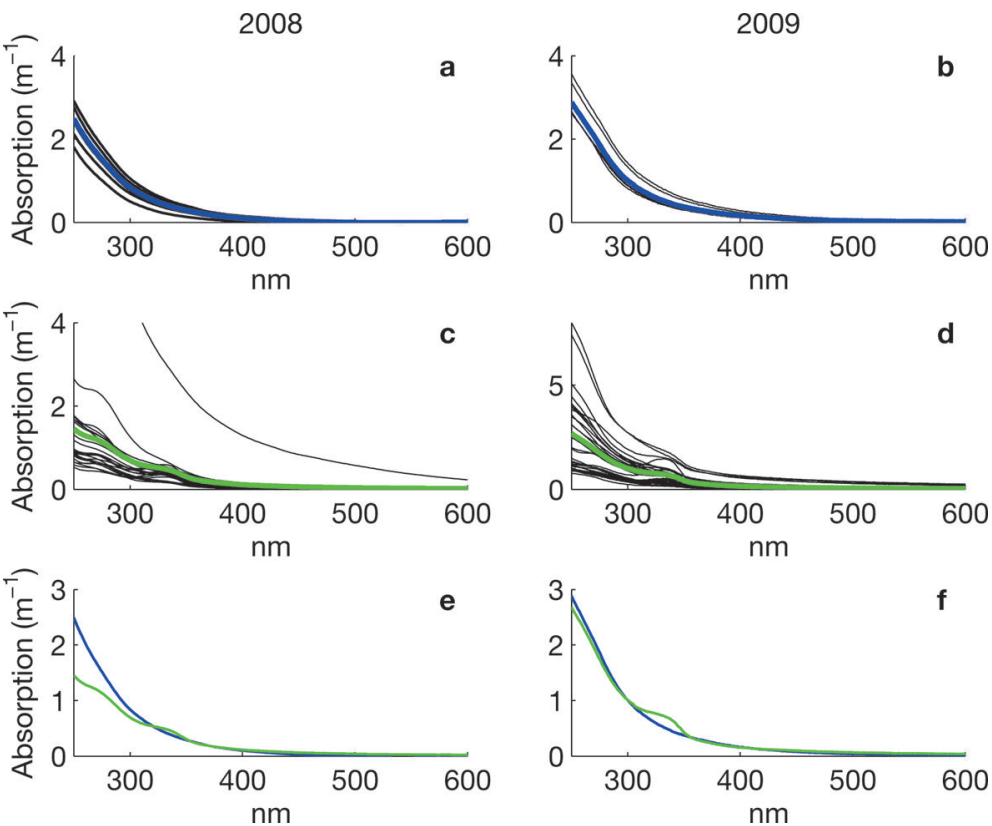

Fig. 2. Absorption spectra for sea-water (a, b) and sea-ice (c, d) samples collected in 2008 and 2009, respectively. Blue and green lines in (a-d) show the mean. The means in 2008 (e) and 2009 ( $f$ ) for sea water (blue) and sea ice (green) are compared. Note the variable $y$-axis scale.

MAA to Chl a ratios up to 0.65 ) and could be detected as high particulate absorption peaks at $\sim 330 \mathrm{~nm}$ (Uusikivi and others, 2010).

From Figure 2c and $d$ it is apparent that many of the absorption spectra in sea ice are often very flat below $350 \mathrm{~nm}$ and do not have the characteristic strong exponential increase in CDOM absorption at shorter wavelengths (e.g. Blough and Del Vecchio, 2002). The samples with these flat absorbance spectra are predominantly from older first-year sea ice, while the younger ice tended to have absorbance spectra similar to that of sea water (besides the distinct absorption peaks also present in some of these samples). This could be partly due to the age of the ice, since either mature sea-ice communities produced this material or sunlight photobleached dissolved material, thereby flattening the absorption spectra. Flatter CDOM absorption spectra at shorter wavelengths have been observed in surface ice layers and for older ice in the Baltic Sea (Uusikivi and others, 2010; Müller and others, 2011).
Our observations indicate that sea ice can support concentrated production of specific light-absorbing compounds, presently of unknown origin or composition, which can be released during ice melt. Values in sea ice are considerably higher than expected from conservative incorporation relative to salinity. The absorption peak at $\sim 330 \mathrm{~nm}$ was particularly distinct in the majority of the seaice samples, while the absorption at $\sim 300 \mathrm{~nm}$ has values expected from simple exponential decay with increasing wavelength. Hence, the ratio of absorption at $330 \mathrm{~nm}$ to that at $300 \mathrm{~nm}\left(\mathrm{a}_{\mathrm{R}}=\mathrm{a}_{330}: \mathrm{a}_{300}\right)$, which was considerably higher in sea ice than in sea water (Table 3), can be used to show that CDOM released from sea ice appears to differ substantially from that of underlying sea water, although the concentration appears similar to sea water. Thus, sea ice does not provide an excess amount of CDOM during melt, as reported for Baffin Bay (Scully and Miller, 2000), but rather is a source of CDOM of different quality (Norman and others, 2011).

Table 3. Optical properties of CDOM in sea water and sea ice. Mean and standard deviation (maximum) are given for $\mathrm{a}_{350}, \mathrm{a}_{375}$ and $\mathrm{a}_{\mathrm{R}}$ (ratio $\left.\mathrm{a}_{330}: \mathrm{a}_{300}\right)$. Range is given for $S . S$ values for sea ice are not given as they could not be computed reliably

\begin{tabular}{|c|c|c|c|c|c|c|c|c|}
\hline Region & $\begin{array}{c}\text { Sea-water } \mathrm{a}_{350} \\
\mathrm{~m}^{-1}\end{array}$ & $\begin{array}{c}\text { Sea-ice } a_{350} \\
\mathrm{~m}^{-1}\end{array}$ & $\begin{array}{c}\text { Sea-water } \mathrm{a}_{375} \\
\mathrm{~m}^{-1}\end{array}$ & $\begin{array}{c}\text { Sea-ice } a_{375} \\
\mathrm{~m}^{-1}\end{array}$ & $\begin{array}{c}\text { Sea-water } S \\
\mathrm{~nm}^{-1}\end{array}$ & $\begin{array}{c}\text { Sea-ice } S \\
\mathrm{~nm}^{-1}\end{array}$ & Sea-water $a_{R}$ & Sea-ice $a_{R}$ \\
\hline \multicolumn{9}{|l|}{2008} \\
\hline Okhotsk & $\begin{array}{l}0.24 \pm 0.08 \\
\quad(0.35)\end{array}$ & $\begin{array}{l}0.18 \pm 0.06 \\
\quad(0.28)\end{array}$ & $\begin{array}{c}0.14 \pm 0.06 \\
(0.22)\end{array}$ & $\begin{array}{l}0.07 \pm 0.04 \\
(0.19)\end{array}$ & $0.020-0.028$ & $\mathrm{n} / \mathrm{a}$ & $\begin{array}{c}0.49 \pm 0.04 \\
(0.53)\end{array}$ & $\begin{array}{c}0.86 \pm 0.28 \\
(1.41)\end{array}$ \\
\hline Saroma & $\begin{array}{c}0.39 \pm 0.01 \\
(0.40)\end{array}$ & $\begin{array}{c}0.32 \pm 0.07 \\
\quad(2.32)\end{array}$ & $\begin{array}{c}0.23 \pm 0.002 \\
(0.23)\end{array}$ & $\begin{array}{c}0.18 \pm 0.04 \\
(1.70)\end{array}$ & 0.020 & $\mathrm{n} / \mathrm{a}$ & $\begin{array}{c}0.54 \pm 0.005 \\
(0.54)\end{array}$ & $\begin{array}{c}0.61 \pm 0.05 \\
(0.70)\end{array}$ \\
\hline \multicolumn{9}{|l|}{2009} \\
\hline Okhotsk & $\begin{array}{c}0.31 \pm 0.02 \\
(0.33)\end{array}$ & $\begin{array}{c}0.45 \pm 0.33 \\
\quad(1.26)\end{array}$ & $\begin{array}{l}0.20 \pm 0.02 \\
\quad(0.22)\end{array}$ & $\begin{array}{c}0.25 \pm 0.23 \\
(0.83)\end{array}$ & $0.0197-0.0222$ & $\mathrm{n} / \mathrm{a}$ & $\begin{array}{c}0.52 \pm 0.01 \\
(0.53)\end{array}$ & $\begin{array}{c}0.68 \pm 0.15 \\
(1.00)\end{array}$ \\
\hline Saroma & $\begin{array}{c}0.55 \pm 0.05 \\
(0.59)\end{array}$ & $\begin{array}{l}0.40 \pm 0.30 \\
\quad(1.08)\end{array}$ & $\begin{array}{c}0.38 \pm 0.04 \\
(0.41)\end{array}$ & $\begin{array}{l}0.19 \pm 0.21 \\
(0.76)\end{array}$ & $0.0175-0.0183$ & $\mathrm{n} / \mathrm{a}$ & $\begin{array}{c}0.57 \pm 0.01 \\
(0.58)\end{array}$ & $\begin{array}{c}0.94 \pm 0.24 \\
(1.34)\end{array}$ \\
\hline
\end{tabular}



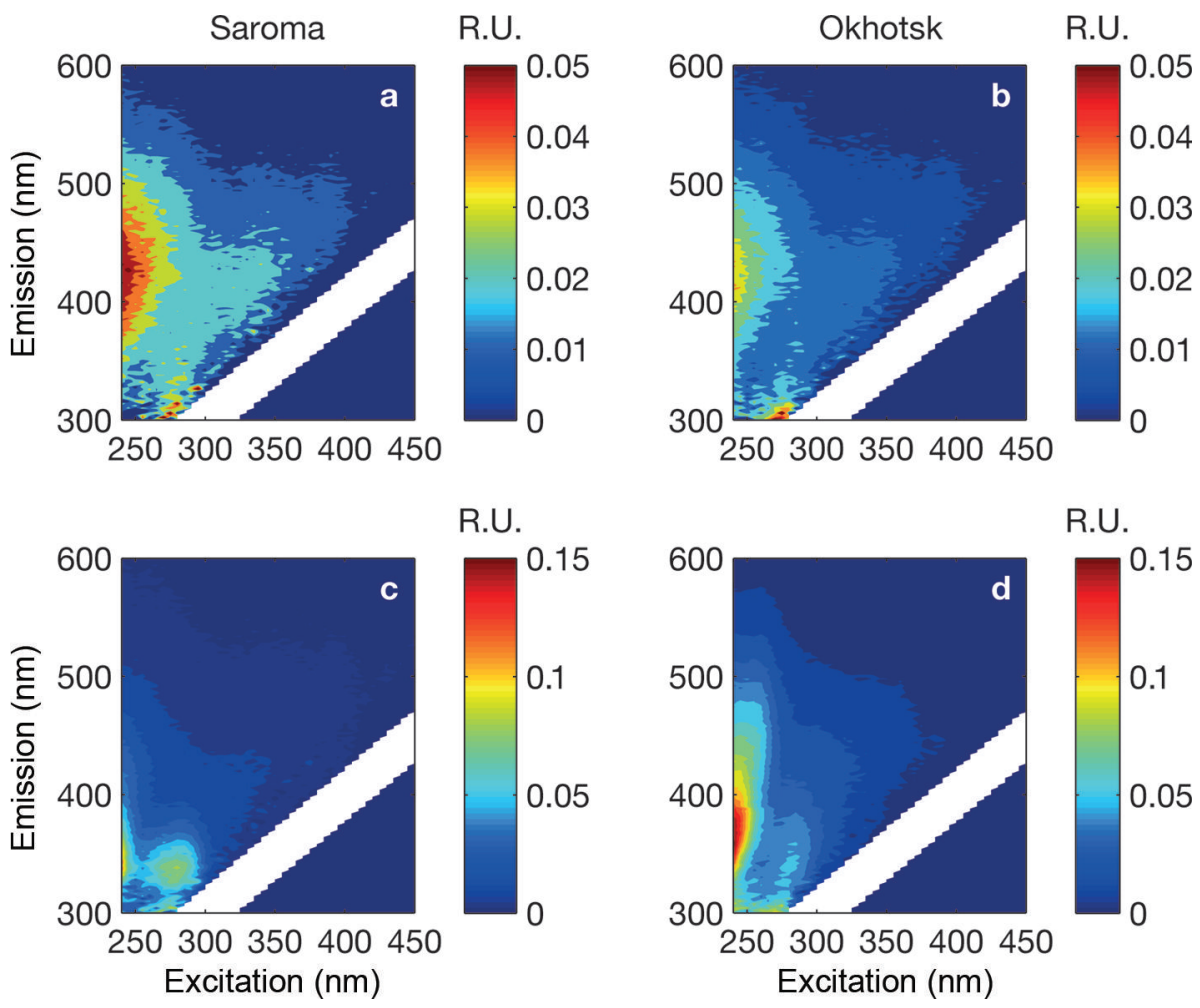

Fig. 3. Typical EEMs in the study region. EEMs shown are means for sea water in Saroma (a), sea water in the Sea of Okhotsk (b), sea ice in Saroma (c) and sea ice in the Sea of Okhotsk (d). Note the difference in intensity scale between sea-water (a, b) and sea-ice samples (c, d).

\section{CDOM fluorescence}

\section{Characteristic fluorescence excitation-emission}

The majority of sea-water samples were dominated by a terrestrial humic-like fluorescence (Fig. 3) with excitation at $250 \mathrm{~nm}$ and maximum emission at $>400 \mathrm{~nm}$ (Coble, 1996). Some sea-water samples had another fluorescent compound with excitation/emission maximum at $\sim 275 / 305 \mathrm{~nm}$. The EEMs in sea ice differed considerably from those in (parent) sea water (Fig. 3), and are dominated by emission below $400 \mathrm{~nm}$, similar to observations in Baltic Sea ice (Stedmon and others, 2007).

\section{PARAFAC components}

Components in the validated PARAFAC model (Table 2) overlap with results from earlier studies. Two of the identified components ( $\mathrm{C} 1$ and $\mathrm{C} 2$ ) had properties that are often referred to as humic-like (Coble, 1996), with broader excitation spectra and emission maxima $>380 \mathrm{~nm}$. The other three components (C3-C5; Table 2) resemble protein-like material, with emission at $<360 \mathrm{~nm}$ (Coble, 1996), overlapping with findings from other studies. For example, C3 resembles tryptophan-like (free or bound to protein) fluorescence in Antarctic sea-ice brines (Stedmon and others, 2011), and C4 and C5 have been referred to as tyrosine-like fluorescence (Coble, 1996; Patasayeva and others, 2004). These are likely not pure compounds but bound to other compounds/molecules, which is why their fluorescence characteristics differ from those of pure amino acids.

Sea-water fluorescence in both Saroma and Okhotsk was dominated by the humic-like component $\mathrm{C} 2$, with a significant negative correlation with salinity and $\delta^{18} \mathrm{O}$ in sea water $(r<-0.76, p<0.01)$, implying a terrigenous source. This relationship could not be found in sea ice. In contrast, sea-ice DOM fluorescence was generally dominated by varying degrees of the protein-like components. To examine whether these compounds are found in excess in sea ice relative to parent sea water, enrichment factors (EFs) were calculated as in Müller and others (2013), with values $>1$ indicative of an excess in sea ice that cannot be explained by conservative incorporation relative to salinity during ice formation (Table 2). The EFs for protein-like components are much higher (median values 8.9-14.0; Table 2) than observed during initial ice formation $(\mathrm{EFs}<3$; Müller and others, 2013, fig. 11). EFs for humic-like material $(\mathrm{EF}<4)$ were considerably lower than for protein-like material, similar to what is found during initial ice formation (Müller and others, 2013). The considerable protein-like accumulation thus points towards biological activity in sea ice during ageing (cf. Stedmon and others, 2007, 2011).

The much higher biomass in sea ice relative to sea water points towards possible accumulation in sea ice as a result of sympagic production. CDOM released during sea-ice melt is therefore compositionally different than that present in parent sea water, and sea ice might therefore be a source of fresh and potentially more labile CDOM (Norman and others, 2011). However, more detailed studies during ice melt are needed to validate this assumption. Norman and others (2011) showed that the material released from sea ice is susceptible to exposure to sunlight and is easily photobleached; therefore, its lifetime could be transient.

\section{CONCLUSIONS}

We have examined the composition of CDOM in sea ice and surface waters in the southern Sea of Okhotsk and the adjacent semi-enclosed Saroma lagoon by resolving the absorbance and fluorescent properties of CDOM. Sea-water 
CDOM shows the typical exponentially decaying absorption spectra and is composed mainly of humic-like material. In sea ice, the absorption spectra deviated significantly from the classical exponential decay spectra (e.g. Bricaud and others, 1981), with distinct absorption peaks in many samples and flatter absorption spectra in the ultraviolet range in older first-year sea ice (Fig. 2). Flat spectra are perhaps a response to exposure to light, as the relatively low latitudes in the study area result in high insolation. This is also supported by recent observations of sea ice in the Baltic Sea (Uusikivi and others, 2010) and the Antarctic (Norman and others, 2011). The analysis of CDOM in sea ice therefore shows evidence for the production of compounds with strong ultraviolet absorption at certain wavelengths, suggestive of production of aromatic and mycosporine-like amino acids within sea ice (cf. Uusikivi and others, 2010). Support for this was found by the fluorescence of CDOM, which showed that protein-like compounds dominated in sea ice and were found in significant excess compared with underlying sea water, as has been found recently in Antarctic sea ice (Stedmon and others, 2011). The enrichment of these compounds in sea ice is much higher than can be explained by incorporation during ice formation (Müller and others, 2013). This suggests production and accumulation of specific protein-like compounds in sea ice (cf. Stedmon and others, 2007, 2011). Thus the material released from melting sea ice is apparently composed of labile material (cf. Norman and others, 2011). Further studies are needed, however, to better understand the role of sea-ice-derived DOM, especially in the highly productive ice edge or marginal ice zones.

\section{ACKNOWLEDGEMENTS}

This work was supported by a bilateral research mobility grant from the Academy of Finland and the Japan Society for Promotion of Science (JSPS) to M.A.G., and the Norwegian Polar Institute. We thank the reviewers and the Scientific Editor Gerhard Dieckmann for constructive comments.

\section{REFERENCES}

Belzile C, Johannessen SC, Gosselin M, Demers S and Miller WL (2000) Ultraviolet attenuation by dissolved and particulate constituents of first-year ice during late spring in an Arctic polynya. Limnol. Oceanogr., 45(6), 1265-1273 (doi: 10.4319/ lo.2000.45.6.1265)

Blough NV and Del Vecchio R (2002) Choromophoric DOM in the coastal environment. In Hansell DA and Carlson CA eds. Biogeochemistry of marine dissolved organic matter. Academic Press, San Diego, CA, 509-546

Bricaud A, Morel A and Prieur L (1981) Absorption by dissolved organic matter of the sea (yellow substance) in the UV and visible domains. Limnol. Oceanogr., 26(1), 43-53 (doi: 10.4319/ lo.1981.26.1.0043)

Coble PG (1996) Characterization of marine and terrestrial DOM in seawater using excitation-emission matrix spectroscopy. Mar. Chem., 51(4), 325-346 (doi: 10.1016/0304-4203(95)00062-3)

Ehn J, Granskog MA, Reinart A and Erm A (2004) Optical properties of melting landfast sea ice and underlying seawater in Santala Bay, Gulf of Finland. J. Geophys. Res., 109(C9), C09003 (doi: 10.1029/2003JC002042)

Ertel JR, Hedges JI, Devol AH, Richey JE and de Nazaré Góes Ribeiro M (1986) Dissolved humic substances of the Amazon River system. Limnol. Oceanogr., 31(4), 739-754 (doi: 10.4319/ lo.1986.31.4.0739)
Furuya K, Hayashi M and Yabushita Y (1998) HPLC determination of phytoplankton pigments using $\mathrm{N}, \mathrm{N}$-dimethylformamide. J. Oceanogr., 54(2), 199-203 (doi: 10.1007/BF02751695)

Granskog M (2000) Observations of particulate matter in the ice of the Sea of Okhotsk and Saroma-ko lagoon. Low Temp. Sci., Ser. A, Data Rep., 58, 63-71

Granskog MA, Macdonald RW, Mundy C-J and Barber DG (2007) Distribution, characteristics and potential impacts of chromophoric dissolved organic matter (CDOM) in Hudson Strait and Hudson Bay, Canada. Continental Shelf Res., 27(15), 2032-2050 (doi: 10.1016/j.csr.2007.05.001)

Granskog MA, Kaartokallio H and Kuosa H (2010) Sea ice in nonpolar regions. In Thomas DN and Dieckmann GS eds. Sea ice. Wiley-Blackwell, Chichester, 531-577

Hansell DA and Carlson CA eds. (2002) Biogeochemistry of marine dissolved organic matter. Academic Press, San Diego

Hill VJ (2008) Impacts of chromophoric dissolved organic material on surface ocean heating in the Chukchi Sea. J. Geophys. Res., 113(C7), C07024 (doi: 10.1029/2007JC004119)

Kimura N and Wakatsuchi M (2004) Increase and decrease of sea ice area in the Sea of Okhotsk: ice production in coastal polynyas and dynamic thickening in convergence zones. J. Geophys. Res., 109(C9), C09S03 (doi: 10.1029/2003JC001901)

Kowalczuk P, Durako MJ, Young $\mathrm{H}$, Kahn AE, Cooper WJ and Gonsior M (2009) Characterization of dissolved organic matter fluorescence in the South Atlantic Bight with use of PARAFAC model: interannual variability. Mar. Chem., 113(3-4), 182-196 (doi: 10.1016/j.marchem.2009.01.015)

Kudoh S, Robineau B, Suzuki Y, Fujiyoshi Y and Takahashi M (1997) Photosynthetic acclimation and the estimation of temperate ice algal primary production in Saroma-ko Lagoon, Japan. J. Mar. Syst., 11(1-2), 93-109 (doi: 10.1016/S0924-7963(96)00031-0)

Martin S, Drucker R and Yamashita K (1998) The production of ice and dense shelf water in the Okhotsk Sea polynyas. J. Geophys. Res., 102(C12), 27 771-27 782 (doi: 10.1029/98JC02242)

McMinn A and Hattori $\mathrm{H}$ (2006) Effect of time of day on the recovery from light exposure in ice algae from Saroma-ko Lagoon, Hokkaido. Polar Biosci., 20, 30-36

McMinn A, Hattori H, Hirawake T and Iwamoto A (2008) Preliminary investigation of Okhotsk Sea ice algae: taxonomic composition and photosynthetic activity. Polar Biol., 31(8), 1011-1015 (doi: 10.1007/s00300-008-0433-0)

Mopper K and Kieber DJ (2002) Photochemistry and the cycling of carbon, sulfur, nitrogen and phosphorus. In Hansell DA and Carlson CA eds. Biogeochemistry of marine dissolved organic matter. Academic Press, San Diego, CA, 455-507

Moran MA and Zepp RG (1997) Role of photoreactions in the formation of biologically labile compounds from dissolved organic matter. Limnol. Oceanogr., 42(6), 1307-1316

Müller S, Vähätalo AV, Granskog MA, Autio R and Kaartokallio H (2011) Behaviour of dissolved organic matter during formation of natural and artificially grown Baltic Sea ice. Ann. Glaciol., 52(57 Pt 2), 233-241 (doi: 10.3189/172756411795931886)

Müller S, Vähätalo AV, Stedmon CA, Granskog MA, Norman L and Aslam SN (2013) Selective incorporation of dissolved organic matter (DOM) during sea ice formation. Mar. Chem., 155, 148-157 (doi: 10.1016/j.marchem.2013.06.008)

Nakatsuka T, Toda M, Kawamura K and Wakatsuchi M (2004) Dissolved and particulate organic carbon in the Sea of Okhotsk: transport from continental shelf to ocean interior. J. Geophys. Res., 109(C9), C09S14 (doi: 10.1029/2003JC001909)

Nomura D, Takatsuka T, Ishikawa M, Kawamura T, Shirasawa K and Yoshikawa-Inoue H (2009) Transport of chemical components in sea ice and under-ice water during melting in the seasonally icecovered Saroma-ko Lagoon, Hokkaido, Japan. Estuar. Coast. Shelf Sci., 81(2), 201-209 (doi: 10.1016/j.ecss.2008.10.012)

Nomura D and 7 others (2010) Nutrient distributions associated with snow and sediment-laden layers in sea ice of the southern Sea of Okhotsk. Mar. Chem., 119(1-4), 1-8 (doi: 10.1016/ j.marchem.2009.11.005) 
Nomura D, McMinn A, Hattori H, Aoki S and Fukuchi M (2011) Incorporation of nitrogen compounds into sea ice from atmospheric deposition. Mar. Chem., 127(1-4), 90-99 (doi: 10.1016/ j.marchem.2011.08.002)

Norman L and 9 others (2011) The characteristics of dissolved organic matter (DOM) and chromophoric dissolved organic matter (CDOM) in Antarctic sea ice. Deep-Sea Res. II, 58(9-10), 1075-1091 (doi: 10.1016/j.dsr2.2010.10.030)

Obernosterer I and Benner R (2004) Competition between biological and photochemical processes in the mineralization of dissolved organic carbon. Limnol. Oceanogr., 49(1), 117-124 (doi: 10.4319/lo.2004.49.1.0117)

Patsayeva S, Reuter R and Thomas DN (2004) Fluorescence of dissolved organic matter in seawater at low temperatures and during ice formation. EARSeL eProc., 3, 227-238

Robineau B, Legendre L, Kishino M and Kudoh S (1997) Horizontal heterogeneity of microalgal biomass in the first-year sea ice of Saroma-ko lagoon (Hokkaido, Japan). J. Mar. Syst., 11(1-2), 81-91 (doi: 10.1016/S0924-7963(96)00030-9)

Ryan KG, McMinn A, Mitchell KA and Trenerry L (2002) Mycosporine-like amino acids in Antarctic sea ice algae, and their response to UVB radiation. Z. Naturforsch. C, 57, 471-477

Scully NM and Miller WL (2000) Spatial and temporal dynamics of colored dissolved organic matter in the north water polynya. Geophys. Res. Lett., 27(7), 1009-1011 (doi: 10.1029/ 1999GL007002)

Shirasawa K and Leppäranta M (2003) Hydrometeorological and sea ice conditions in Saroma-ko lagoon, Hokkaido, Japan. In Proceedings of Seminar on Sea Ice Climate and Marine Environments in the Okhotsk and Baltic Seas: the Present Status and Prospects, 10-13 September 2001, Seili, Finland. (Report Series in Geophysics 46) University of Helsinki Press, Helsinki, 161-168

Shirasawa K, Leppäranta M, Saloranta T, Kawamura T, Polomoshnov A and Surkov G (2005) The thickness of coastal fast ice in the Sea of Okhotsk. Cold Reg. Sci. Technol., 42(1), 25-40 (doi: 10.1016/ j.coldregions.2004.11.003)

Stedmon CA and Bro R (2008) Characterizing dissolved organic matter fluorescence with Parallel Factor Analysis: a tutorial. Limnol. Oceanogr.: Meth., 6, 572-579

Stedmon CA, Thomas DN, Granskog M, Kaartokallio H, Papadimitriou $\mathrm{S}$ and Kuosa $\mathrm{H}$ (2007) Characteristics of dissolved organic matter in Baltic coastal sea ice: allochthonous or autochthonous origins? Environ. Sci. Technol., 41(21), 7273-7279 (doi: 10.1021/ es071210f)
Stedmon CA, Thomas DN, Papadimitriou S, Granskog MA and Dieckmann GS (2011) Using fluorescence to characterize dissolved organic matter in Antarctic sea ice brines. J. Geophys. Res., 116(G3), G03027 (doi: 10.1029/2011JG001716)

Steinberg DK, Nelson NB, Carlson CA and Prusak A (2004) Production of chromophoric dissolved organic matter (CDOM) in the open ocean by zooplankton and the colonial cyanobacterium Trichodesmium spp. Mar. Ecol. Progr. Ser., 267, 45-56 (doi: 10.3354/meps267045)

Thurman EM ed. (1985) Organic geochemistry of natural waters. (Developments in Biogeochemistry 2) D Riedel, Dordrecht

Toyota T, Kawamura T, Ohshima KI, Shimoda $\mathrm{H}$ and Wakatsuchi $\mathrm{M}$ (2004) Thickness distribution, texture and stratigraphy, and a simple probabilistic model for dynamical thickening of sea ice in the southern Sea of Okhotsk. J. Geophys. Res., 109(C6), C06001 (doi: 10.1029/2003JC002090)

Toyota T, Takatsuji S, Tateyama K, Naoki K and Ohshima KI (2007) Properties of sea ice and overlying snow in the southern Sea of Okhotsk. J. Oceanogr., 63(3), 393-411 (doi: 10.1007/s10872007-0037-2)

Ukita J, Kawamura T, Tanaka N, Toyota T and Wakatsuchi M (2000) Physical and stable isotopic properties and growth processes of sea ice collected in the southern Sea of Okhotsk. J. Geophys. Res., 105(C9), 22 083-22 093 (doi: 10.1029/1999JC000013)

Uusikivi J, Vähätalo AV, Granskog MA and Sommaruga R (2010) Contribution of mycosporine-like amino acids and colored dissolved and particulate matter to sea ice optical properties and ultraviolet attenuation. Limnol. Oceanogr., 55(2), 703-713 (doi: 10.4319/lo.2010.55.2.0703)

Vähätalo AV and Zepp RG (2005) Photochemical mineralization of dissolved organic nitrogen to ammonium in the Baltic Sea. Environ. Sci. Technol., 39(18), 6985-6992 (doi: 10.1021/ es050142z)

Woźniak B and Dera J (2007) Light absorption in sea water. (Atmospheric and Oceanographic Sciences Library 33) Springer, New York

Yamamoto M, Tanaka N and Tsunogai S (2001) Okhotsk Sea intermediate water formation deduced from oxygen isotope systematics. J. Geophys. Res., 106(C12), 31 075-31084 (doi: 10.1029/2000JC000754)

Yamamoto M, Watanabe S, Tsunogai S and Wakatsuchi M (2002) Effects of sea ice formation and diapycnal mixing on the Okhotsk Sea intermediate water clarified with oxygen isotopes. Deep-Sea Res. I, 49(7), 1165-1174 (doi: 10.1016/S0967-0637(02)00032-8) 